\title{
Response of Pasteurella piscicida and Flexibacter maritimus to skin mucus of marine fish
}

\author{
Beatriz Magariños, Francisco Pazos, Ysabel Santos, Jesús L. Romalde, \\ Alicia E. Toranzo
}

Departmento de Microbiología y Parasitología, Facultad de Biología, Universidad de Santiago de Compostela, E-15706 Santiago de Compostela, Spain

\begin{abstract}
The antibacterial activity present in the skin mucus of turbot Scophthalmus maximus, seabream Sparus aurata and seabass Dicentrarchus labrax against Pasteurella piscicida and Flexibacter maritimus was evaluated. Using assays on agar plates, none of the mucus samples from the above fish showed any antibacterial activity against $F$ maritimus isolates. Turbot mucus inhibited the growth of the $P$ piscicida but mucus from seabream and seabass did not. Assays in liquid systems to determine the survival of the above pathogens in the presence of skin mucus corroborated the results obtained by the agar plate method. The bactericidal properties of the mucus were lost after heat treatment at $\mathrm{pH} 3.5$ and all skin mucus samples displayed activity against Staphylococcus aureus ATCC 25923, a strain resistant to lysozyme. These findings indicated that thermolabile substances other than lysozyme were responsible for the antibacterial activity in mucus of marine fish. Enzymatic and heat treatments of the mucus also showed that factors other than complement were involved and that the active component(s) was likely a glycoprotein. Regardless of the source of isolation and degree of virulence, all $P$. piscicida and F. maritimus strains adhered strongly to the skin mucus of the 3 fish species tested. Taking all of the foregoing results into consideration, it appears that whereas a possible portal of entry for F. maritimus into the fish body is the skin, in P. piscicida another pathway must be involved.
\end{abstract}

KEY WORDS: Pasteurella piscicida - Flexibacter maritimus - Marine fish - Skin mucus Antibacterial activity. Adhesiveness

\section{INTRODUCTION}

Bacterial adhesion to tissue surfaces of fish is important during the initial stages of infection (Thune et al. 1993, Toranzo \& Barja 1993). However, fish body surfaces are covered with a layer of mucus with antibacterial properties that protects against colonization by potential pathogens (Harrel et al. 1976, Austin \& McIntosh 1988). These antimicrobial effects of body mucus are therefore valuable to fish as a first line of defense against infection.

Pasteurellosis and flexibacteriosis, caused respectively by the halophilic bacteria Pasteurella piscicida and Flexibacter maritimus, are fish diseases that cause problems in marine aquaculture. $P$. piscicida is one of the main agents responsible for economic losses in cultured yellowtail Seriola quinqueradiata in Japan. Indeed, since 1990 this bacterium has also caused serious disease outbreaks in the culture of seabream Sparus aurata and seabass Dicentrarchus labrax in European countries (reviews by Toranzo et al. 1991, Kitao 1993, Kusuda \& Salati 1993). F. maritimus is widely distributed among marine fish cultured mainly in Japan and Europe (Campbell \& Buswell 1982, Wakabayashi et al. 1986, Bernardet et al. 1990). In Spain, pathological problems attributable to this microorganism have increased considerably during the last few years and it poses a threat to the culture of turbot (Scophthalmus maximus) and salmon (Salmo salar and Oncorhynchus kisutch) (Devesa et al. 1989, Pazos et al. 1993, Toranzo et al. 1993).

The mode of transmission and route of infection involved in these diseases are still uncertain. The importance of skin as a portal of entry for Pasteurella piscicida and Flexibacter maritimus has not been explored, Consequently, the role of the external mucus 
layer as a barrier to infection is not known. In the present study, the antibacterial activity of skin mucus from different marine fish species against several $P$. piscicida and $F$. maritimus isolates was studied and the nature of the biologically active substance(s) in the mucus was investigated. In addition, the ability of both pathogens to adhere to glass surfaces coated with mucus from the fish was also determined.

\section{MATERIALS AND METHODS}

Strains. Strains of Pasteurella piscicida and Flexibacter maritimus from different sources were used in this work (see Table 1). Pathogenic isolates of Vibrio anguillarum (R-82 and RG-111) and V. damsela (ATCC 33539) (Toranzo \& Barja 1993) were included in the study for comparative purposes. Staphylococcus aureus ATCC 25923, a strain resistant to lysozyme, was used as a control. The $P$. piscicida strains were cultured on Brain Heart Infusion Agar (BHIA) (Oxoid, Ltd, Basingstoke, Hampshire, UK) supplemented with $\mathrm{NaCl}$ to a final concentration of $2 \%$ (BHIA-2) and the F. maritimus isolates were cultured on a $F$. maritimus medium (FMM) (peptone, 0.5\%; sodium acetate, $0.001 \%$; yeast extract, $0.5 \%$; and agar, $1.5 \%$; prepared in seawater) as described by Pazos et al. (1993)

Infectivity trials. After fish stocks were determined to be free of bacterial pathogens by microbiological analysis of the internal organs, infectivity trials were performed as previously described (Magarinos et al. 1992b) in fingerling turbot, seabream, and seabass (average weights 8 to $10 \mathrm{~g}$ ). The challenge was administered as an intraperitoneal injection of $0.1 \mathrm{ml}$ of bacterial suspension containing from $10^{3}$ to $10^{8}$ cells (10 fish per dose). Control fish were similarly injected with saline solution. Mortalities were attributed to the inoculated bacterium if the injected organism was recovered in pure culture from the internal organs. The degree of virulence $\left(\mathrm{LD}_{50}\right.$, lethal dose $50 \%$ ) was determined by the Reed \& Müench (1938) method. In the case of Flexibacter maritimus, this assay was only performed in turbot using a single dose (between $10^{6}$ and $10^{7}$ cells per fish).

Bactericidal assay of the suriace mucus. The mucus was scraped from the skin of 8 healthy turbot, 8 seabream, and 8 seabass with a glass slide which was passed along the animals from the caudal peduncle to the operculum. The mucous material was dissolved in sterile seawater or saline solution (SS: $0.85 \% \mathrm{NaCl}$ ) $(0.1 \mathrm{ml}$ mucus per $2 \mathrm{ml}$ seawater or $\mathrm{SS})$, mixed thoroughly, filter sterilized, and stored at $-30^{\circ} \mathrm{C}$ until used.

The antibacterial activity of the different skin mucus preparations was tested by 2 different procedures. The assays were conducted in triplicate and the means and their associated standard deviation (SD) values were calculated

(1) Assay on solid media: The classical disc diffusion method on agar plates was employed (Fouz et al. 1990). Bacteria were resuspended in SS or seawater to a concentration of $10^{5}$ to $10^{\mathrm{b}}$ cells $\mathrm{ml}^{-1}$ and then seeded on plates of BHIA-2 or FMM, depending on the strain tested. After an absorption period of $15 \mathrm{~min}$, sterile $6 \mathrm{~mm}$ diameter discs impregnated with $20 \mu \mathrm{l}$ of the mucus preparations were applied to the agar plates. Incubation was at $25^{\circ} \mathrm{C}$ for $24 \mathrm{~h}$ for Pasteurella piscicida, Vibrio anguillarum, and $V$. damsela or $72 \mathrm{~h}$ for Flexibacter maritimus, and at $37^{\circ} \mathrm{C}$ for $24 \mathrm{~h}$ for Staphylococcus aureus. The antibacterial activity was evident as a zone without bacterial growth around the disc.

The presence of lysozyme activity in the skin mucus was evaluated microbiologically on mucus preparations that had been heated to $100^{\circ} \mathrm{C}$ for $10 \mathrm{~min}$ following adjustment to various $\mathrm{pH}$ values ( 3 to 9) (Takahashi et al. 1986)

(2) Survival and growth ability of the strains in skin mucus: This assay was conducted only with turbot mucus because in the previous plate assay this was the only mucus to show an antimicrobial effect. The isolates were inoculated at a concentration of approximately $10^{5}$ cells $\mathrm{ml}^{-1}$ (Pasteurella piscicida, Vibrio damsela and $V$. anguillarum) or $10^{6}$ cells $\mathrm{ml}^{-1}$ (Flexibacter maritimus) in sterile seawater supplemented with skin mucus $\left(100 \mu \mathrm{l} \mathrm{ml^{-1 }}\right)$. At different times, samples $(0.1 \mathrm{ml})$ were taken and spread onto plates of BHIA-2 or FMM media. The number of colonies was counted after incubation at $25^{\circ} \mathrm{C}$ for 24 or $72 \mathrm{~h}$ (depending on the strain tested). For reference purposes, viable counts were also made on bacteria suspended in seawater alone.

Effect of enzymatic and heat treatments on the antimicrobial activity of mucus. The effect of various enzymes on the antibacterial activity of the skin mucus of turbot (against Pasteurella piscicida and Staphylococcus aureus) and of seabass and seabream (against $S$. aureus) was evaluated using solutions $\left(1 \mathrm{mg} \mathrm{ml}^{-1}\right)$ in $\mathrm{SS}$ of the following enzymes (Sigma): proteinase $\mathrm{K}$, trypsin, $\beta$-galactosidase, achromopeptidase, lysozyme, $\beta$-amylase, and lipase. Mucus preparations were mixed with the enzyme solutions (ratio 1:1) and incubated for 1 h at $37^{\circ} \mathrm{C}$. The residual activities of the mucus preparations were assayed by the paper disk diffusion method on BHIA-2 plates previously seeded with the $P$. piscicida or with $S$. aureus. Disks impregnated separately with untreated mucus and enzyme solutions were included as controls.

To determine the possible involvement of complement in the antibacterial activity, the mucus preparations were heated as follows: $47^{\circ} \mathrm{C}$ for $30 \mathrm{~min}, 56^{\circ} \mathrm{C}$ for 
20 min and $80^{\circ} \mathrm{C}$ for 10 min. Following this, the mucus preparations were assayed for antibacterial activity by the disc diffusion/agar plate method.

Adherence to skin mucus. The assay was performed by the method of Krovaceck et al. (1987). Mucus preparation $(50 \mu l)$ was placed on glass slides and left overnight to air-dry following fixation for $20 \mathrm{~min}$ with absolute methyl alcohol. Ten $\mathrm{ml}$ of bacterial suspensions $\left(2 \times 10^{5}\right.$ cells $\left.\mathrm{ml}^{-1}\right)$ in SS or seawater was added to mucus-coated slides in petri plates. The plates were incubated at room temperature for $1 \mathrm{~h}$ with continuous gentle shaking and washed several times with sterile seawater or S.S. The slides were then air-dried at room temperature for 12 to $14 \mathrm{~h}$, fixed with absolute methyl alcohol (20 min at room temperature), and stained with crystal violet for $2 \mathrm{~min}$. Following this, the slides were washed and air-dried. Finally, the slides were observed under the light microscope and the number of bacteria attached to $1 \mathrm{~mm}^{2}$ of the mucus-coated glass slides was determined. The assays were performed in duplicate.

To rule out possible influence of the alcohol fixation treatment on adherence and, hence, to simulate more natural conditions, we also repeated the adherence experiments using only air-dried mucus. Control tests using uncoated glass slides were performed. In addition, strains of Vibrio harveyi and $V$. fischeri (kindly supplied by J. J. Borrego, Departamento de Microbiología, Facultad de Ciencias, Universidad de Málaga, Spain), lacking the ability to adhere to fish mucus, were used as negative controls.

\section{RESULTS}

\section{Bactericidal assay}

Table 1 summarizes the findings with the various mucus samples and bacteria tested. All Flexibacter maritimus strains tested resisted the antimicrobial activity of skin mucus from the different fish species evaluated. All isolates of Pasteurella piscicida were sensitive to the antibacterial action of turbot mucus but were resistant to the action of seabream and seabass skin mucus. The strains of Vibrio anguillarum tested showed similar results to $P$ piscicida; $V$. damsela was resistant to all mucus samples; and the Staphylococcus aureus strain was susceptible to all of the mucus samples.

The Staphylococcus aureus ATCC 25923, employed as an indicator for the presence of lysozyme, was very sensitive to the action of all of the mucus samples assayed. However, the sensitivity of this bacterium to the different skin mucus samples disappeared when the samples were heated at $100^{\circ} \mathrm{C}$ in the acidic buffer

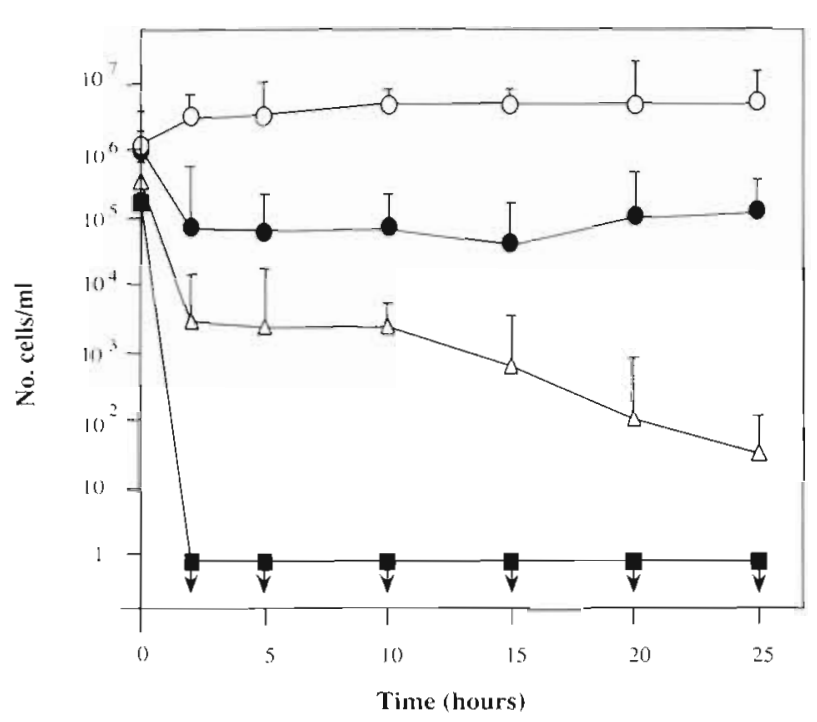

Fig. 1. Survival of representative strains of Pasteurella pisclcida and Flexibacter maritimus in preparations of skin mucus of turbot Scophthalmus maximus. (ロ) P. piscicida DI 21; (-) F. maritimus NCIMB 2154. Vibrio anguillarum R-82 ( $\triangle$ ) and $V$. damsela ATCC $33539(O)$ isolates were included for comparison. Arrowheads indicate values below the detection limit. Vertical bars represent standard deviations

( $\mathrm{pH} 3.5)$. These results were obtained whether or not the mucus was dissolved in seawater or SS.

Fig 1 is representative of the survival observed when the various Flexibacter maritimus and Pasteurella piscicida isolates were suspended in seawater containing turbot mucus. The F. maritimus isolates all survived the exposure, although initially they experienced a slight drop in the population of viable cells. In contrast, turbot mucus exerted a strong and rapid antimicrobial effect on the $P$. piscicida isolates, no viable $P$. piscicida cells being detectable within $2 \mathrm{~h}$. Indeed, by $30 \mathrm{~min}$, no viable $P$. piscicida cells were detectable (data not shown). The effect of turbot mucus on the Vibrio anguillarum strains was less marked than on $P$. piscicida and was negative on the $V$. damsela isolate. All isolates survived well in the controls (seawater) maintaining the same or higher viable cell populations than present at time zero (data not shown).

\section{Properties of the antibacterial molecule(s)}

The effect of heat and enzymatic treatments on the antibacterial substance(s) in the mucus is shown in Table 2. The antibacterial activity was completely lost on treatments at $80^{\circ} \mathrm{C}$ for $10 \mathrm{~min}$. Moreover, the mucus dissolved in $\mathrm{SS}$ (free of $\mathrm{Ca}^{2+}$ and $\mathrm{Mg}^{2+}$ ) showed the same antibacterial activity as that of mucus dissolved in seawater. These data suggest that the antibacterial 
Table 1. Effect of the skin mucus from different marine fish against Pasteurella piscicida and Flexibacter martimus strains

\begin{tabular}{|c|c|c|c|c|c|c|}
\hline \multirow[t]{2}{*}{ Strains } & \multirow[t]{2}{*}{ Origin } & \multirow{2}{*}{ Donor ${ }^{a}$} & \multirow[t]{2}{*}{ Pathogenicity ${ }^{b}$} & \multicolumn{3}{|c|}{ Source of mucus } \\
\hline & & & & Turbot & Seabream & Seabass \\
\hline \multicolumn{7}{|l|}{ P. piscicida } \\
\hline DI 21 & Seabream, Spain & A. E. Toranzo & $10^{3}-10^{5}$ & $\mathrm{~S}(11 \pm 0.5)^{c}$ & $\mathrm{R}$ & $\mathrm{R}$ \\
\hline DI 71 & Seabream. Spain & A. E. Toranzo & $10^{3}-10^{5}$ & $S(13 \pm 1)$ & $\mathrm{R}$ & $\mathrm{R}$ \\
\hline B 32 & Seabream, Spain & J. Borrego & $10^{3}-10^{4}$ & $\mathrm{~S}(12 \pm 1)$ & $\mathrm{R}$ & $\mathrm{R}$ \\
\hline B 51 & Seabass, Spain & J. Borrego & $10^{3}-10^{5}$ & $S(11 \pm 0.2)$ & $\mathrm{R}$ & $\hat{\mathrm{R}}$ \\
\hline 10831 & Seabass, France & F. Baudin-Laurencin & $10^{3}-10^{4}$ & $S(11 \pm 0.5)$ & $\mathrm{R}$ & $\mathrm{R}$ \\
\hline IT -1 & Seabream, Italy & G. Giorgetti & $10^{3}-10^{5}$ & $\mathrm{~S}(12 \pm 0.5)$ & $\mathrm{R}$ & $\mathrm{R}$ \\
\hline MP-7801 & Yellowtail, Japan & T Kitao & $10^{3}-10^{5}$ & $S(12 \pm 1)$ & $\mathrm{R}$ & $\mathrm{R}$ \\
\hline EPOY-8803-II & Red grouper, Japan & K. Muroga & $>10^{8}$ & $\mathrm{~S}(12 \pm 2)$ & $\mathrm{R}$ & $\mathrm{R}$ \\
\hline ATCC 29690 & Yellowtail, Japan & ATCC & $>10^{8}$ & $S(13 \pm 0.5)$ & $\mathrm{R}$ & $\mathrm{R}$ \\
\hline ATCC 17911 & White perch, USA & ATCC & $10^{3}-10^{6}$ & $\mathrm{~S}(12 \pm 0.2)$ & $\mathrm{R}$ & $\mathrm{R}$ \\
\hline P-3333 & Amberjack, Japan & R. Kusuda & $10^{4}-10^{5}$ & $S(14 \pm 1)$ & $\mathrm{R}$ & $\mathrm{R}$ \\
\hline ATLIT 2 & Striped bass, Italy & A. Colorni & $10^{4}-10^{5}$ & $S(17 \pm 0.4\}$ & $\mathrm{R}$ & $\mathrm{R}$ \\
\hline \multicolumn{7}{|l|}{ F. maritimus } \\
\hline NCIMB 21.53 & Black seabream, Japan & NCIMB & NT & $\mathrm{R}$ & $\mathrm{R}$ & $\mathrm{R}$ \\
\hline NCIMB 2154 & Red seabream, Japan & NCIMB & $>3 \times 10^{6}$ & $\mathrm{R}$ & $\mathrm{R}$ & $\mathrm{R}$ \\
\hline NCIMB 2158 & Dover sole, UK & NCIMB & $<1 \times 10^{7}$ & $\mathrm{R}$ & $R$ & $\mathrm{R}$ \\
\hline 386 & Red seabream, Japan & H. Wakabayashi & NT & $\mathrm{R}$ & $\mathrm{R}$ & $\mathrm{R}$ \\
\hline 394 & Red seabream, Japan & H. Wakabayashi & NT & $\mathrm{R}$ & $\mathrm{R}$ & $\mathrm{R}$ \\
\hline SP 9.1 & Atlantic salmon, Spain & A. E. Toranzo & $<1 \times 10^{7}$ & $\mathrm{R}$ & $\mathrm{R}$ & $\mathrm{R}$ \\
\hline SE 30.1 & Pacific salmon, Spain & A. E. Toranzo & $\mathrm{NT}$ & $\mathrm{R}$ & $\mathrm{R}$ & $\mathrm{R}$ \\
\hline RA 79.1 & Turbot, Spain & A. E. Toranzo & NT & $\mathrm{R}$ & $\mathrm{R}$ & $\mathrm{R}$ \\
\hline RP 67.1 & Turbot, Spain & A. E. Toranzo & $<8 \times 10^{6}$ & $\mathrm{R}$ & $\mathrm{R}$ & $\mathrm{R}$ \\
\hline RP 70.1 & Turbot, Spain & A. E. Toranzo & NT & $R$ & $\mathrm{R}$ & $\mathrm{R}$ \\
\hline RPM 539.1 & Turbot, Spain & A. E. Toranzo & $>1 \times 10^{7}$ & $\mathrm{R}$ & $\mathrm{R}$ & $\mathrm{R}$ \\
\hline RPM 562.1 & Turbot, Spain & A. E. Toranzo & $<1 \times 10^{6}$ & $\mathrm{R}$ & $\mathrm{R}$ & R \\
\hline \multicolumn{7}{|l|}{ Controls: } \\
\hline \multicolumn{7}{|c|}{ Vibrio anguillarum } \\
\hline $\mathrm{R}-82(\mathrm{O} 1)^{\mathrm{d}}$ & Turbot, Spain & A. E. Toranzo & $10^{2}-10^{4}$ & $S(10 \pm 0.5\}$ & $\mathrm{R}$ & $\mathrm{R}$ \\
\hline $\mathrm{RG}-111(\mathrm{O} 2)$ & Turbot, Spain & A. E. Toranzo & $10^{3}-10^{4}$ & $S(11 \pm 0.2)$ & $\mathrm{R}$ & $R$ \\
\hline \multicolumn{7}{|l|}{$V$ damsela } \\
\hline ATCC 33539 & Damselfish, USA & ATCC & $10^{3}-10^{4}$ & $\mathrm{R}$ & $\mathrm{R}$ & $\mathrm{R}$ \\
\hline \multicolumn{7}{|c|}{ Staphylococcus aureus } \\
\hline ATCC 25923 & Clinical isolate, USA & ATCC & NT & $S(18 \pm 0.5)$ & $S(18 \pm 0)$ & $S(17+0)$ \\
\hline \multicolumn{7}{|c|}{$\begin{array}{l}\text { "ATCC: American Type Culture Collection, Rockville, MD, USA; NCIMB: National Collections of Industrial and Marine } \\
\text { Bacteria, Aberdeen, Scotland, UK }\end{array}$} \\
\hline \multicolumn{7}{|c|}{$\begin{array}{l}{ }^{\mathrm{h}} \text { The pathogenicity of } P \text {. piscicida and Vibrio controls is expressed as the range of } \text { LD }_{50} \text { values on different fish species } \\
\text { (seabream, turbot and trout) (Magarinos et al. 1992b. Toranzo \& Barja 1993). NT. not tested }\end{array}$} \\
\hline \multicolumn{7}{|c|}{$\begin{array}{l}\text { "R: resistant; S: sensitive. Values in parentheses indicate the diameter (mean } \pm S D \text { ) of inhibition zones in mm. } \\
{ }^{\mathrm{d}} \text { Serotype of the } V \text {. anquillarum strains used }\end{array}$} \\
\hline
\end{tabular}

activity in mucus was not due to complement but rather to other thermolabile substance(s)

The antibacterial activity exhibited by the various preparations against Pasteurella piscicida, Vibrio anguillarum and Staphylococcus aureus was totally eliminated by treatment with proteinase $\mathrm{K}$ and $\beta$-galactosidase and partially eliminated by trypsin and achromopeptidase. None of the other nonproteolytic enzymes had any effect. Table 2 illustrates the results for turbot mucus but the same findings held true for seabass and seabream mucus. These results suggest that the antibacterial substance is a glycoprotein.

\section{Adherence assays}

All Pasteurella piscicida and Flexibacter maritimus isolates adhered strongly to the turbot, seabream, and seabass skin mucus, values for attached cells ranging from $10^{2}$ to $10^{3}$ cells $\mathrm{mm}^{-2}$ depending on the strain. Differences between replicates were always lower than $0.5 \%$ F. maritimus strains also showed some (slight) adherence to uncoated slides, but $P$. piscicida strains did not bind at all to uncoated glass surfaces. As expected, the Vibrio strains used as negative controls showed no adherence to coated or uncoated slides. 
Table 2. Activity of the turbot Scophthalmus maximus mucus against Pasteurella piscicida, Vibrio anguillarum, and Staphylococcus aureus after the enzymatic and heat treatment. + : positive; $(+)$ : moderate; -: negative

\begin{tabular}{|lccc|}
\hline Inhibition treatment & $\begin{array}{c}\text { P. piscicida } \\
(8 \text { strains })\end{array}$ & $\begin{array}{c}\text { V. anguillarum } \\
\text { R-82 }\end{array}$ & $\begin{array}{c}\text { S. aureus } \\
\text { ATCC } 25923\end{array}$ \\
\hline Enzymes & & & \\
Proteinase K & - & - & - \\
Trypsin & $(+)(8)^{\mathrm{d}}$ & $(+)(7)$ & $(+)(10)$ \\
$\begin{array}{l}\beta \text {-Galactosidase } \\
\text { Achromopeptidase }\end{array}$ & - & - & - \\
$\begin{array}{l}\beta \text {-Amylase } \\
\text { Lipase }\end{array}$ & $+(14)$ & $(+)(7)$ & $(+)(9)$ \\
Lysozyme & $+(14)$ & $+(10)$ & $+(16)$ \\
Temperature & $+(14)$ & $+(11)$ & $+(17)$ \\
$47^{\circ} \mathrm{C}, 30$ min & & & $+(17)$ \\
$56^{\circ} \mathrm{C}, 20$ min & $+(14)$ & $+(10)$ & $+(17)$ \\
$80^{\circ} \mathrm{C}, 10$ min & $(+)(7)$ & $(+)(6)$ & $(+)(9)$ \\
Mucus without treatment & $+(14)$ & $+(10)$ & $+(17)$ \\
a Values in parentheses indicate the diameter of inhibition zones in mm & \\
\hline
\end{tabular}

seabass (Ceschia et al. 1990, Baudin-Laurencin et al. 1991, Toranzo et al. 1991) but never in turbot (Toranzo et al. 1993).

Specific and nonspecific antimicrobial factors including complement, lysozyme, C-reactive protein, immunoglobulins, proteases, lectin-like molecules, and glycoproteins have been reported to occur in mucus (Alexander \& Ingram 1992). These substances may function as natural defence factors by preventing the colonization of fish surfaces by microorganisms and the penetration of bacteria into the body.

It is well recognized that the temperatures for inactivation of fish complement range from 42 to $50^{\circ} \mathrm{C}$ (depending on the fish species) and that the activation of the complement system is dependent on the presence of $\mathrm{Ca}^{2+}$ and $\mathrm{Mg}^{2+}$ (Sakai 1992). In our study, the activities of the different mucus preparations were inhibited at temperatures higher than $56^{\circ} \mathrm{C}$. Further, mucus dissolved in saline solu-

Adherence of the strains was not affected by the salt solution in which the mucus was dissolved (SS or seawater). In addition, the mucus fixation method did not influence the ability of the strains to bind to coated slides.

\section{DISCUSSION}

Pasteurella piscicida and Flexibacter maritimus constitute 2 phenotypically, serologically and molecularly homogeneous taxa (Wakabayashi et al. 1986, Bernardet et al. 1990, Toranzo et al. 1991, Magariños et al. 1992a, b, Pazos et al. 1993) and the results of this study confirm that homogeneity. Constituent strains of each taxon were uniform in their responses to the antibacterial effects of mucus and in their ability to attach to mucus.

The bactericidal assays demonstrated that skin mucus of turbot, seabream, and seabass did not contain compounds that inhibited the growth of Flexibacter maritimus isolates, a result similar to that reported by Al-Harbi \& Austin (1992) for a fish-pathogenic Cytophaga-like bacterium. This resistance to the antibacterial effects of mucus could help to explain the fact that the primary site of infection by $F$. maritimus is the body surface, where ulcerative skin lesions are the lesions typically produced (Campbell \& Buswell 1982, Devesa et al. 1989, Toranzo et al. 1993). With Pasteurella piscicida, all strains were susceptible to turbot mucus but not to seabream and seabass mucus. These observations may well explain why all disease outbreaks in Europe due to $P$. piscicida have to date occurred in seabream and tion (free of divalent cations) showed the same antibacterial properties as mucus dissolved in seawater. These data indicate that the antibacterial activities of the skin mucus from the fish species tested were not due to complement.

In the present work, the loss of mucus activity after heat treatment at $\mathrm{pH} 3.5$ and the sensitivity displayed by Staphylococcus aureus (ATCC 25923) demonstrated that lysozyme was not the main factor responsible for the activity of mucus. Overall, the data indicated that other thermolabile antimicrobial substances exist in the skin mucus of marine fishes. These data are in accordance with those described by Takahashi et al. (1987), Austin \& McIntosh (1988) and Fouz et al. (1990). In fact, the results of the enzymatic treatments revealed that the antimicrobial molecules were totally inhibited by proteinase $\mathrm{K}$ and by $\beta$-galactosidase, suggesting that they are glycoproteins.

The strains of Pasteurella piscicida and Flexibacter maritimus (regardless of their origin and degree of virulence) adhered strongly to glass slides coated with mucus from all of the fish species tested. However, because $P$. piscicida was highly sensitive to the antimicrobial action of turbot skin mucus, the bacterium would likely be rapidly killed after attachment to the surface of turbot, thus negating turbot skin as a portal of entry. These findings indicate that a strong bacterial adhesion to an organ or tissue does not necessarily result in the occurrence of disease. Obviously, for prognostic purposes, it is worth knowing whether the mucus associated with a given organ or tissue is bactericidal.

The homogeneity in the adherence patterns exhibited by the strains of Flexibacter maritimus and Pas- 
teurella piscicida found in this study was similar to that found for strains of Vibrio damsela (Fouz 1993) and V. vulnificus biotype 2 (Amaro et al. 1993). In contrast, strains of Aeromonas hydrophila and $V$. anguillarum described by Krovaceck et al. (1987) were heterogeneous in this property.

The results reported here suggest collectively that a possible portal of entry for Flexibacter maritimus into the fish body can be the skin. However, with Pasteurella piscicida the pathways of entry may vary depending on the host. With some fish, infection may follow ingestion of the pathogen. Regardless of the route of entry (invasion) employed by a pathogen once it has succeeded in invading the fish, its success in establishing an infection or causing a disease will depend on other factors, including its ability to neutralize or evade the immune system of the fish and its ability to scavenge the nutrients required for its growth.

Acknowledgements. This investigation was supported by Grants MAR 91-1133-C02-01 and AGF-94-136-C03-01 from the Comisión Interministerial de Ciencia y Tecnologia (CICYT), and XUGA 20004A94 from Xunta de Galicia, Spair, and by EUREKA project No. EU-374 between Spain and Norway. B.M. and F.P. thank the Xunta de Galicia for Research Fellowships. The kind donation of the bacterial strains used in this stucly is gratefully acknowledged.

\section{LITERATURE CITED}

Alexander JB, Ingram GA (1992) Noncellular nonspecific defence mechanism of fish. In: Faisal M, Hetrick FM (eds) Annual review of fish diseases. Pergamon Press, New York, p 249-279

Al-Harbi AH, Austin B (1992) Influence of skin and gut mucus from turbot (Scophthalmus maximus L.) on the survival of a fish-pathogenic Cytophaga-like bacterium (CLB). Bull Eur Ass Fish Pathol 12:80-82

Amaro C, Biosca EG, Fouz B, Esteve C. Garay E (1993) Experimental induction of vibriosis produced by $V$ vulnificus biotype 2 in eels by immersion. Abstracts, 6 th Int Conf Eur Ass Fish Pathol, Brest, France. European Association of Fish Pathologists, Brest, p 18

Austin B, Mclntosh D (1988) Natural antibacterial compounds on the surface of rainbow trout, Salmo gairdneri. J Fish Dis 11:275-277

Baudin-Laurencin F, Pepin JF, Raymond JC (1991) First observation of an epizootic of pasteurellosis in farmed and wild fish of the French mediterranean coasts. Abstracts, 5th Int Conf Eur Ass Fish Pathol, Budapest, Hungary. European Association of Fish Pathologists, Budapest, p 1

Bernardet JF, Campbell AC, Buswell JA (1990) Flexibacter maritimus is the agent of 'black patch necrosis' in Dover sole in Scotland. Dis aquat Org 8:233-237

Campbell AC, Buswell JA (1982) An investigation into the bacterial aetiology of 'black patch necrosis' in Dover sole, Solea solea L. J Fish Dis 5:495-508

Ceschia G, Giorgettı G, Bovo G (1990) Grave epizoozia da Pasteurella piscicida in specie eurihaline del Nord Adriatico. Boll Soc Ital Patol Ittica 4:11-17

Devesa S, Barja JL, Toranzo AE (1989) Ulcerative skin and fin lesions in reared turbot. Scophthalmus maximus (L.).

Responsible Subject Editor: T. Evelyn, Nanaimo, B.C., Canada
J Fish Dis 12:323-333

Fouz B (1993) Caracterización de Vibrio damsela: nuevo patógeno en acuicultura marina. Doctoral dissertation, Universidad de Santiago de Compostela

Fouz B, Devesa S, Gravninger K, Barja JL, Toranzo AE (1990) Antibacterial action of the mucus of turbot. Bull Eur Ass Fish Pathol 10.56-59

Harrell LW, Etlinger HM, Hodgins HO (1976) Humoral factors important in resistance of salmonid fish to bacterial disease. II Anti-Vibrio anguillarum activity in mucus and observations on complement. Aquaculture 7:363-370

Kitao T (1993) Pasteurellosis. In: Inglis $V$, Roberts RJ, Bromage NR (eds) Bacterial diseases of fish. Blackwell, Oxford, p 159-165

Krovaceck K, Faris A, Ahne W. Hånsson J (1987) Adhesion of Aeromonas hydrophila and Vibrio anguillarum to fish cells and to mucus-coated glass slides. FEMS microbiol Lett 42:85-89

Kusuda R, Salati F (1993) Major bacterial diseases affecting mariculture in Japan. In: Faisal M, Hetrick FM (eds) Annual review of fish diseases. Pergamon Press, New York, p $69-85$

Magariños B, Romalde JL, Bandín I, Fouz B, Toranzo AE (1992a) Phenotypic, antigenic and molecular characterization of $P$. piscicida strains isolated from fish. Appl environ Microbiol 58:3316-3322

Magariños B, Santos Y, Romalde JL, Rivas C, Barja JL, Toranzo AE (1992b) Pathogenic activities of the live cells and extracellular products of the fish pathogen Pasteurella piscicida. J gen Microbiol 138:2491-2498

Pazos F, Santos Y, Núnez S, Toranzo AE (1993) Characterization of Flexibacter maritimus isolated in northwest of Spain. Abstracts, 6th Int Conf Eur Ass Fish Pathol, Brest, France. European Association of Fish Pathologists, Brest, p 8

Reed LJ, Müench M (1938) A simple method of estimating fifty percent end points. Am J Hyg 27:493-497

Sakai DK (1992) Repertoire of complement in immunological defense mechanism of fish. In: Faisal M, Hetrick FM (eds) Annual review of fish diseases. Pergamon Press, New York, p 223-247

Takahashi Y, Itami T, Konegawa K (1986) Enzymatic properties of partially purified lysozyme from the skin mucus of carp. Bull Jap Soc scient Fish 52:1209-1214

Takahashi Y, Kajiwaki T, Itami T, Okamoto I (1987) Enzymatic properties of the bacteriolytic substances in the skin mucus of yellowtail. Nippon Suisan Gakk 53:425-431

Thune RL, Stanley LA, Cooper RK (1993) Pathogenesis of Gram-negative bacterial infections in warmwater fish. In: Faisal M, Hetrick FM (eds) Annual review of fish diseases. Pergamon Press, New York, p 37-68

Toranzo AE, Barja JL (1993) Virulence factors of bacteria pathogenic for cold water fish. In: Faisal M. Hetrick FM (eds) Annual review of fish diseases. Pergamon Press, New York, p 5-36

Toranzo AE, Barreiro S, Casal JF, Figueras A, Magariños B, Barja JL (1991) Pasteurellosis in cultured gllthead seabream (Sparus aurata): first report in Spain. Aquaculture 99:1-15

Toranzo AE, Novoa B, Romalde JL, Nuñez S, Devesa S, Mariño E. Silva R, Martínez E, Figueras A, Barja JL (1993) Microflora associated with healthy and diseased turbot (Scophthalmus maximus) from three farms in Northwest Spain. Aquaculture 114:189-202

Wakabayashi H, Hikida M, Masumura K (1986) Flexibacter mantimus sp. nov., a pathogen of manne fishes. Int $J$ syst Bacteriol 36:396-398

Manuscript first received: May 2, 1994

Revised version accepted: November 10, 1994 